\title{
Llibres i revistes rebuts
}

\section{Llibres}

MÓDENES, Juan Antonio i altres (2003). El territori i la mobilitat migratòria dels joves a Catalunya, (Aportacions; 22). Barcelona: Secretaria General de Joventut, Generalitat de Catalunya.

CAPDEVILA, Manel; FERRER, Marta (2003). Els menors estrangers indocumentats no acompanyats (MEINA), (Justícia i Societat; 24). Barcelona: Centre d'Estudis Jurídics i Formació Especialitzada, Generalitat de Catalunya.

\section{Revistes}

Debats, núm. 84, primavera de 2004, València: Institució Alfons el Magnànim.

Quaderns De Bona Font: "Dona i Immigració», març de 2004, l'Hospitalet de Llobregat: Ajuntament de l'Hospitalet de Llobregat.

Red 12 URB-AL: "Mujer y ciudad», núm. 1, febrer de 2004, Barcelona: Diputació de Barcelona.

Revista de Cooperación Internacional (International Cooperation), núm. 9, 2003, Madrid. Trayectorias. Revista de Ciencias Sociales, núm. 13/14, abril de 2004, Mèxic: Universidad Autónoma de Nuevo León. 